\title{
Failure of Complex Supplementation of Minimal Cultures to Elicit a Shift-up Response in Pseudomonas putida
}

\author{
By J. K. COLLINS AND S. CONDON \\ Department of Dairy and Food Microbiology, University College, Cork, Ireland
}

(Received 2 April 1975; revised 24 September 1975)

\begin{abstract}
SUMMARY
The addition of complex supplements (particularly amino acids) to cultures of Pseudomonas putida growing on a good carbon source did not result in a substantial increase in the growth rate. Amino acids entered the cells within $30 \mathrm{~s}$ of addition and reached significant internal pool concentrations. Endogenous amino acid biosynthesis was quickly inhibited (about $75 \%$ ), with a substantial sparing of the original carbon source. Within 20 min of supplementation significant respiration of added amino acids was detected, yet the ATP pool size did not increase and the bacteria did not grow faster.

The RNA content of $P$. putida growing in complex medium differed from that of enteric bacteria in that, although it varied with growth rate, it was not substantially larger than the RNA content of bacteria grown in a minimal medium with a good carbon and energy source. The rate of RNA accumulation on shift-up remained substantially unchanged on supplementation if the minimal medium had a carbon source producing fast growth, and did not increase for about $30 \mathrm{~min}$ if the carbon source was relatively poor. In other respects RNA synthesis was similar to that of the enteric bacteria, being stringently controlled, inhibited by trimethoprim and continuing in the presence of chloramphenicol. It is proposed that growth of $P$. putida in complex media is limited by the rate of synthesis of stable RNA.
\end{abstract}

\section{INTRODUCTION}

Since the classic work of Schaechter, Maaløe \& Kjeldgaard (1958) showing the dependency of the macromolecular composition of Salmonella typhimurium on growth rate, much research has been devoted to understanding the regulation of macromolecular synthesis in the enteric bacteria. It is now accepted that bacteria can exist in a continuum of physiological states, each characterized by a particular macromolecular composition which depends on the nutrients available and which supports a characteristic growth rate at a particular temperature. Supplementation of minimal cultures of enteric and related bacteria with amino acids, purines and pyrimidines results in a transition to a macromolecular composition characteristic of a rich environment, and to an increased growth rate. This increased growth rate is believed to be a consequence of an increased ribosome content, with a sparing of the original carbon and energy source through regulation of endogenous amino acid biosynthesis when the amino acids are supplied in the external environment (Neidhardt \& Magasanik, I960; Maaløe \& Kjeldgaard, 1966).

Pseudomonas putida does not respond to complex supplementation of its environment as enteric bacteria do. The growth rate of $P$. putida in complex media like nutrient broth is not appreciably faster than that in a minimal medium at the expense of a readily metabolizable carbon and energy source, such as asparagine (Condon, 1967). This observation implies a 
fundamental difference in metabolic regulation between enteric bacteria and $P$. putida. Addition of preformed amino acids should spare the organism both carbon and energy. As a consequence of such saving, enteric bacteria are able to grow much faster, but $P$. putida is not. This study was initiated to elucidate why $P$. putida is unable to respond in this way.

One possibility is that $P$. putida does not possess the mechanisms, characteristic of the enteric bacteria, necessary to regulate endogenous biosynthesis of amino acids. If so, addition of supplements of amino acids to $P$. putida cultures would not lead to carbon and energy sparing. In this paper, we demonstrate that $P$. putida has the mechanisms necessary to regulate endogenous biosynthesis of amino acids and does spare its carbon and energy source on complex supplementation. Evidence is provided that $P$. putida lacks the mechanisms needed to increase its rate of stable ribonucleic acid synthesis on supplementation of fast-growing minimal cultures with amino acids, and so cannot take advantage of the energy and carbon spared.

\section{METHODS}

Bacterial strains. Strains A90 and A775 of Pseudomonas putida (Stanier, Palleroni \& Doudoroff, 1966) were obtained from the Department of Bacteriology and Immunology, University of California, Berkeley, California, U.S.A. An isoleucine-valine auxotroph of $P$. putida A90 was isolated by penicillin counterselection of $N$-methyl- $N^{\prime}$-nitro- $N$-nitrosoguanidine-treated cells and was designated $P$. putida A9o ilv ${ }^{-}$. Salmonella typhimurium LT2, the classic genetic strain, was used as a comparison.

Growth media and growth measurements. The basal medium used contained (per litre): $\mathrm{KH}_{2} \mathrm{PO}_{4}, 6.8 \mathrm{~g} ; \mathrm{Na}_{2} \mathrm{HPO}_{4}, 7 \cdot \mathrm{rg} ;\left(\mathrm{NH}_{4}\right)_{2} \mathrm{SO}_{4}, \mathrm{I} \cdot 0 \mathrm{~g} ; \mathrm{MgSO}_{4}, 0.6 \mathrm{~g} ; \mathrm{CaCl}_{2} .2 \mathrm{H}_{2} \mathrm{O}, 79 \mathrm{mg}$; $\mathrm{FeSO}_{4} \cdot 7 \mathrm{H}_{2} \mathrm{O}, 2 \mathrm{mg}$; $\left(\mathrm{NH}_{4}\right)_{6} \mathrm{Mo}_{7} \mathrm{O}_{24} \cdot 4 \mathrm{H}_{2} \mathrm{O}, 0.2 \mathrm{mg}$; nitrilotriacetic acid, $0.2 \mathrm{~g}$; Hutner's metals '44' (Cohen-Bazire, Sistrom \& Stanier, I957), I ml. Carbon sources and amino acids (for concentrations, see Table $\mathrm{I}$ ) were added after separate sterilization by autoclaving or membrane filtration depending on heat stability. For determination of growth rate, liquid cultures ( $100 \mathrm{ml}$ or less) were grown in $250 \mathrm{ml}$ Erlenmeyer flasks, with shaking, in a Gallenkamp metabolic shaking incubator. The growth temperature was $30 \pm 0.2{ }^{\circ} \mathrm{C}$. Growth was measured as extinction at $660 \mathrm{~nm}$ using a Pye Unicam SP 500 spectrophotometer. The relationship between dry weight and extinction was linear over the range o to $220 \mu \mathrm{g}$ dry wt $/ \mathrm{ml}$ and an $E_{660}$ of $0 . \mathrm{I}$ was equivalent to $34 \mu \mathrm{g}$ dry wt bacteria $/ \mathrm{ml}$.

Shift experiments. Shift-up experiments were performed with cultures growing exponentially in minimal medium. When exponential growth was established the culture was divided; the desired supplement was added to one portion, and the other was retained as a control. For shift-down experiments, exponentially-growing cultures in amino acidsupplemented asparagine minimal medium were centrifuged, washed in 0.I M-phosphate buffer and resuspended either in minimal asparagine medium, or in the original medium as a control.

Protein and RNA content. Protein determinations were made by the method of Lowry et al. (195I). RNA determinations were made with the orcinol reagent (Munro \& Fleck, 1966).

Measurement of ATP pool sizes. The ATP pool in P. putida A9o cultures was measured by using a modified luciferase assay. The ATP of exponentially-growing cultures was extracted by $30 \%$ (w/v) $\mathrm{HClO}_{4}$ (Cole, Wimpenny \& Hughes, 1967), and assayed by the method of Forrest \& Walker (1965).

Incorporation of $\left[{ }^{14} \mathrm{C}\right]$ carbon source into bacteria. Uptake of radioactive carbon sources into cellular material from the growth medium was monitored by transferring $2 \mathrm{ml}$ culture 
samples into equal volumes of $10 \%(\mathrm{w} / \mathrm{v})$ trichloroacetic acid (TCA) at 0 to $2{ }^{\circ} \mathrm{C}$ and holding at that temperature for at least $30 \mathrm{~min}$. The TCA suspensions were then applied to membrane filters (Oxoid, pore size $0.45 \mu \mathrm{m}$ ) and the precipitate washed five times with $3 \mathrm{ml}$ of ice-cold $5 \%(\mathrm{w} / \mathrm{v})$ TCA. The filters were dried and placed in polyethylene liquid scintillation counting vials in the presence of $10 \mathrm{ml}$ scintillation fluid which contained $5 \mathrm{~g}$ 2,5-diphenyloxazole (PPO) and $50 \mathrm{mg} \mathrm{I,4-di-2(5-phenyloxazolyl)} \mathrm{benzene} \mathrm{(POPOP)/1} \mathrm{tolu-}$ ene. Radioassays were performed in a Nuclear Chicago Unilux II liquid scintillation spectrometer.

Measurement of RNA synthesis. The rate of uptake of $\left[{ }^{14} \mathrm{C}\right]$ uracil into cellular macromolecules was monitored as c.p.m. in the TCA precipitate. Bacteria were prelabelled by growth for $18 \mathrm{~h}$ in the presence of $\left.{ }^{14} \mathrm{C}\right]$ uracil and then transferred to fresh medium containing $\left[{ }^{14} \mathrm{C}\right]$ uracil $(0.02 \mu \mathrm{Ci} / \mathrm{ml})$ and unlabelled uracil $(20 \mu \mathrm{g} / \mathrm{ml})$. Cytosine and thymine $(20 \mu \mathrm{g} / \mathrm{ml})$ were added to counteract the uptake of label into DNA. Incorporation was monitored as described above.

Depletion of $\left[{ }^{14} C\right]$ carbon source from the medium. Acid-precipitated samples of the growing cultures were passed through membrane filters, and $0.5 \mathrm{ml}$ samples of the filtrate were added to counting vials containing $9.5 \mathrm{ml}$ counting solution and assayed in the liquid scintillation spectrometer. The counting solution (selected for its suitability for aqueous samples) consisted of $5 \mathrm{~g}$ PPO, $50 \mathrm{mg}$ POPOP and $80 \mathrm{~g}$ naphthalene/1 of solvent (xyleneI,4-dioxan-ethanol, $5: 5: 3$, by vol.).

Measurement of ${ }^{14} \mathrm{CO}_{2}$ evolution. For experiments involving the evolution of ${ }^{14} \mathrm{CO}_{2}$, a procedure analogous to that of McGinnis \& Paigen (1969) was adopted. Compressed air was passed through $\mathrm{I} \cdot \mathrm{O} \mathrm{M}-\mathrm{NaOH}$, then through a sterile cotton-wool plug into the culture chamber (a large sealed test tube, $45 \times 200 \mathrm{~mm}$, capacity $\mathrm{I} 00 \mathrm{ml}$ ). This tube was fitted with a gas inlet, an aerator, a gas outlet and an injecting valve. The gas from the culture chamber passed through a vapour trap (an empty glass vial submersed in an ice bath) and then through a fine glass needle into a tube containing $\mathrm{Io} \mathrm{ml}$ of trapping solution (ethanolaminemethanol, 30:70, v/v). Samples were collected by changing the trapping solution every Io min. The ${ }^{14} \mathrm{CO}_{2}$ content of the ethanolamine-methanol solution was determined by placing $5 \mathrm{ml}$ in a counting vial containing $5 \mathrm{ml}$ of scintillation fluid (4 g PPO, 100 mg POPOP/l of toluene-methanol, 85: $15, \mathrm{v} / \mathrm{v}$ ), and counting as above.

Amino acid isotopic competition. The method of Abelson (1954) was modified. Cultures growing exponentially in minimal media were divided into two $40 \mathrm{ml}$ portions when the density reached about $35 \mu \mathrm{g}$ dry wt $/ \mathrm{ml}$. To one was added the desired amino acid supplement and to the other an equal volume of distilled water. After $5 \mathrm{~min}, \mathrm{Io} \mu \mathrm{Ci}$ of uniformly labelled $\left[{ }^{14} \mathrm{C}\right]$ carbon source was added to both cultures and the populations were allowed to double. The cultures were then harvested and washed twice with prechilled $0.85 \% \mathrm{NaCl}$. The fractionation procedure used was that of Abelson, Bolton \& Aldous (1952). The protein concentrations were determined by the procedure of Lowry et al. (I95I). The purified protein residues were hydrolysed with $6 \mathrm{M}-\mathrm{HCl}$ at $110{ }^{\circ} \mathrm{C}$ for $24 \mathrm{~h}$. Excess $\mathrm{HCl}$ was then removed by evaporation. Cellulose thin-layers and the solvent systems of Heathcote \& Haworth (1969) were used to separate and identify the amino acid constituents of the protein hydrolysate. The radioactivity of the individual amino acids was determined in situ with a Nuclear Chicago Actigraph III paper chromatogram scanner fitted with a thin-layer attachment. The degree of inhibition is expressed as the extent to which exogenously supplied amino acids inhibit the incorporation of their endogenously synthesized counterparts into protein.

Reagents. L-[U- $\left.{ }^{14} \mathrm{C}\right]$ asparagine, D- $\left[\mathrm{U}-{ }^{14} \mathrm{C}\right]$ glucose, $\left[{ }^{2-14} \mathrm{C}\right]$ uracil and Chlorella $\left[\mathrm{U}-{ }^{14} \mathrm{C}\right]-$ 
protein hydrolysate were obtained from the Radiochemical Centre, Amersham, Buckinghamshire. All other biochemicals were obtained from Sigma and were of the highest purity available.

\section{RESULTS}

While the specific growth rates and doubling times of $P$. putida A90 varied in minimal media at $30^{\circ} \mathrm{C}$ with the carbon and energy source (Table I), complex supplements had little effect on growth rate, and no classic shift-up response was observed when complex supplements were added to cultures growing in a minimal medium with asparagine or succinate as carbon source (e.g. Fig. I a). The effect was not confined to this single strain: P. putida A775 yielded a similar result (e.g. Fig. I $b$ ) although addition of Casamino acids to a minimal asparagine culture did cause a slight increase in growth rate after 40 to $90 \mathrm{~min}$. When the carbon source of the minimal medium supported a slow growth rate (e.g. pyruvate), supplementation with amino acids did cause a shift-up in growth rate of $P$. putida A90 but only after a delay of 30 to 50 min (e.g. Figs. 2 and $6 b$ ). This shift-up pattern was similar to that observed when a slow-growing minimal pyruvate culture was supplemented with asparagine alone (Fig. 6b).

\section{Transport of amino acids}

To test whether the lack of effect of amino acids on growth rate resulted from their inability to enter $P$. putida A90, the uptake of radioactivity from $\left[{ }^{14} \mathrm{C}\right]$ protein hydrolysate into acid-precipitable material was measured over a short time interval following amino acid supplementation of a minimal asparagine culture. Uptake of the amino acid supplement could be detected within $30 \mathrm{~s}$ of addition. It was computed from the specific radioactivity of the protein hydrolysate that $75 \%$ of the bacterial dry weight material synthesized in the 12 min period after amino acid supplementation originated from the added amino acids.

\section{Feedback inhibition of amino acid biosynthesis}

The amino acid isotopic competition approach (Abelson, 1954) was used to determine the extent of control of amino acid biosynthetic pathways through feedback inhibition of enzyme activity. Incorporation of radioactivity from $\left[{ }^{14} \mathrm{C}\right]$ asparagine or $\left[{ }^{14} \mathrm{C}\right]$ glucose into the protein synthesized over one doubling was reduced by $70 \%$ on addition of a complete supplement of amino acids $(20 \mu \mathrm{g}$ of each $/ \mathrm{ml})$, indicating substantial reduction in endogenous amino acid biosynthesis. This reduction was observed in all cases tested, indicating that exogenous amino acids entered and inhibited the biosynthesis of most if not all of their endogenous counterparts (Table 2). With arginine, valine, isoleucine, leucine, histidine, lysine, phenylalanine, tyrosine, proline, cysteine and methionine, supplementation inhibited endogenous biosynthesis between 70 and $100 \%$, indicating tight regulation of the biosynthesis of these amino acids.

Addition of only aspartate and glutamate to the medium (I00 $\mu \mathrm{g}$ of each $/ \mathrm{ml}$ ) caused a lesser inhibition of endogenous biosynthesis of amino acids as compared with a complete supplement (Table 3). The reduction in endogenous synthesis of the amino acids not synthesized from aspartate and glutamate was not nearly so great as when the complete amino acid supplement was used (Table 2), indicating that the inhibition of each biosynthetic sequence is inhibited by its own end product.

\section{Sparing of carbon and energy source by exogenously-supplied amino acids}

Since exogenously-supplied amino acids drastically reduced endogenous synthesis (presumably through feedback inhibition), the carbon and energy source should be spared 


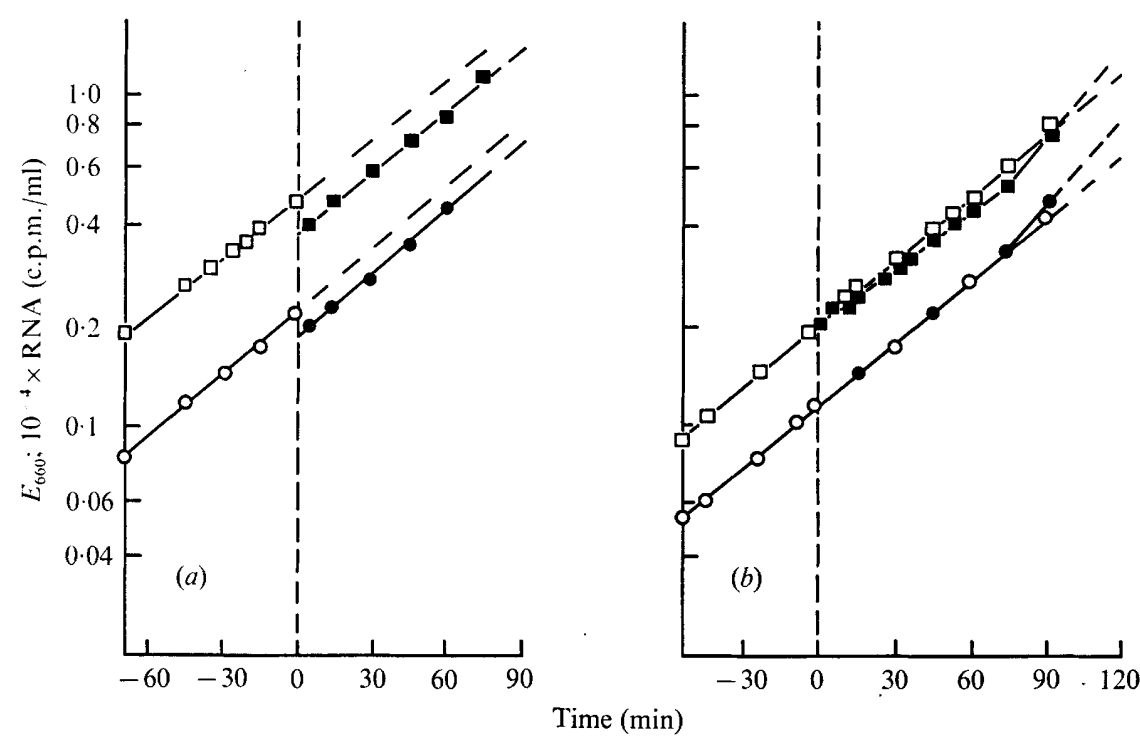

Fig. I. Growth $\left(E_{660}\right)$ and RNA synthesis (c.p.m./ml of $\left[{ }^{14} \mathrm{C}\right]$ uracil uptake into TCA precipitate) during a shift-up experiment with $P$. putida strains A90 $(a)$ and A775 $(b)$. Casamino acids $(0 \cdot 2 \%$, w/v) were added at time zero to exponentially-growing $(0.2 \%, w / v)$ asparagine cultures. $O$, Growth in minimal asparagine; $\bullet$, growth in minimal asparagine + Casamino acids; $\square$, RNA in minimal asparagine; $\mathbf{n}, \mathrm{RNA}$ in minimal asparagine + Casamino acids.

Table I. Growth rates of Pseudomonas putida A90 in various media at $30{ }^{\circ} \mathrm{C}$

$\begin{array}{ccc}\text { Specific } & \text { Doubling } \\ \text { growth rate } & \begin{array}{c}\text { time } \\ \left(\mathrm{h}^{-1}\right)\end{array} & \text { (min) }\end{array}$

Brain-heart infusion (Oxoid)

Nutrient broth (Oxoid)

Minimal asparagine $(0 \cdot 2)+$

Casamino acids $(0 \cdot 2)$

Minimal asparagine $(0.2)$

Minimal succinate $(0 \cdot 2)$

Minimal citrate $(0 \cdot 2)$

Minimal benzoate $(0 \cdot 2)$

$\begin{array}{ll}I \cdot 04 & 40 \\ I \cdot 04 & 40 \\ I \cdot 00 & 42 \\ & \\ 0.93 & 45 \\ 0.93 & 45 \\ 0.87 & 48 \\ 0.83 & 50\end{array}$

$\quad$ Medium*
Minimal glutamine $(0 \cdot 2)$
Minimal glucose $(0 \cdot 2)$
Minimal aspartate $(0 \cdot 2)$
Minimal aspartate $(0 \cdot 2)+$
glucose $(0 \cdot 2)$
Minimal pyruvate
Minimal malonate $(0 \cdot 4)$

* Concentrations $(\%, w / v)$ are given in parentheses.

substantially by amino acid supplementation. The rate of depletion of radioactive asparagine from an exponentially-growing culture of $P$. putida A90 was measured before and after amino acid supplementation (Fig. $3 a$ ), and addition of the supplement did reduce the rate of asparagine utilization. In a similar experiment with $S$. typhimurium LT2 growing at the expense of radioactive glucose the sparing effect was greater (Fig. $3 b$ ).

In minimal medium the sole carbon and energy source is metabolized by aerobic bacteria in two ways: a portion finds its way into cellular macromolecules, and the rest is respired as $\mathrm{CO}_{2}$ to provide energy. Experiments were designed to see if amino acid supplementation spared the growth substrate molecules being channelled into these two separate areas of metabolism. Since most cellular macromolecules can be precipitated by acid, the effect of amino acid supplementation on the uptake of radioactive asparagine from the medium 

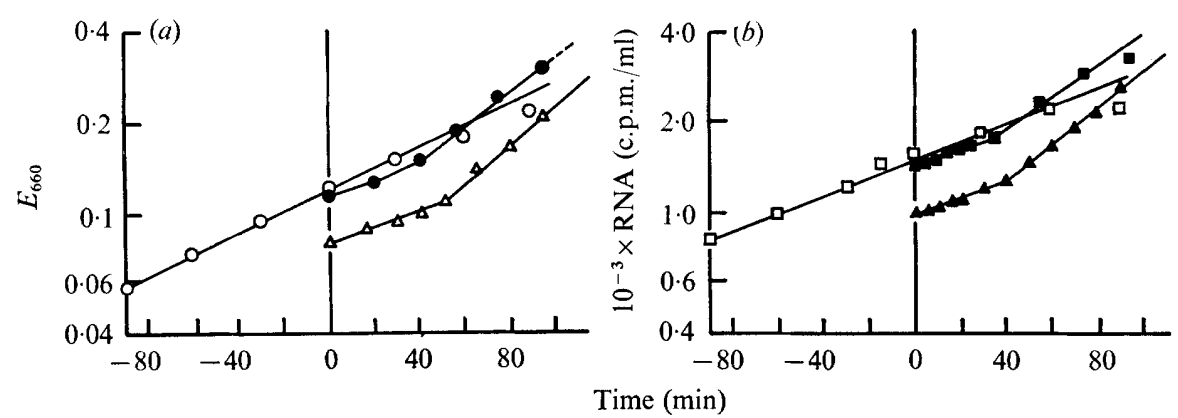

Fig. 2. (a) Growth $\left(E_{660}\right)$ and $(b)$ RNA synthesis (c.p.m./ml of $\left[{ }^{14} \mathrm{C}\right]$ uracil uptake into TCA precipitate) during shift-up experiments with $\boldsymbol{P}$. putida A90. Casamino acids or asparagine were added at zero time to exponentially-growing minimal pyruvate cultures. For concentrations, see Table I. (a) $\bigcirc$, Growth in minimal pyruvate; $\bullet$, growth in pyruvate + Casamino acids; $\triangle$, growth in pyruvate + asparagine. $(b) \square$, RNA in minimal pyruvate; $\mathbf{\square}$, RNA in pyruvate + Casamino acids; $\boldsymbol{\Lambda}, \mathrm{RNA}$ in pyruvate + asparagine.

Table 2. Inhibition of incorporation of radioactivity from $\left[{ }^{14} \mathrm{C}\right]$ asparagine into amino acids of hydrolysed protein of $P$. putida A9o by an exogenous supplement of amino acids

The basal medium, containing $20 \mu \mathrm{g}$ of each of the 20 naturally occurring amino acids $/ \mathrm{ml}$, was incubated at $30^{\circ} \mathrm{C}$. After $5 \mathrm{~min},\left[{ }^{14} \mathrm{C}\right]$ asparagine $(0 \cdot 2 \mu \mathrm{Ci} / \mathrm{ml})$ was added, and uptake of radioactivity measured as described in Methods.

\begin{tabular}{lccc} 
& \multicolumn{4}{c}{$\begin{array}{l}\text { Endogenous biosynthesis* } \\
\text { (c.p.m./100 } \mu \mathrm{g} \text { protein hydrolysate) }\end{array}$} \\
Amino acid & Unsupplemented & Supplemented & $\begin{array}{c}\text { Percentage } \\
\text { inhibition } \dagger\end{array}$ \\
Alanine & 2818 & 1346 & 52 \\
Arginine & 5627 & 1445 & 74 \\
Aspartate & 4327 & $283 \mathrm{I}$ & 35 \\
Glutamate & 6090 & 2772 & 54 \\
Serine & 890 & 742 & 17 \\
Glycine & 1854 & 742 & 60 \\
Threonine & 1563 & 792 & 49 \\
Valine & 1381 & $<300$ & $>78$ \\
Isoleucine & 1090 & $<300$ & $>72$ \\
Leucine & 1890 & $<300$ & $>84$ \\
Histidine & $409 \mathrm{I}$ & 574 & 86 \\
Lysine & 7818 & 2198 & 72 \\
Phenylalanine & 2118 & $<300$ & $>86$ \\
Tyrosine & 2072 & $<300$ & $>86$ \\
Proline & 3272 & 594 & 82 \\
Cysteine and & & & 74 \\
cystine & 3545 & 910 & $>86$ \\
Methionine & 2072 & $<300$ &
\end{tabular}

* Minimum detectable level of radioactivity was 300 c.p.m.

$\uparrow$ Calculated as: $\frac{\text { c.p.m. unsupplemented - c.p.m. supplemented }}{\text { c.p.m. unsupplemented }} \times 100$.

into TCA-precipitable material was measured. Supplementation decreased the rate of utilization of carbon source molecules for macromolecular synthesis (Fig. 4). Increasing the amino acid supplement fivefold did not increase the sparing effect. In a similar experiment with $S$. typhimurium, addition of amino acids to a $\left[{ }^{14} \mathrm{C}\right]$ glucose minimal culture gave a much greater sparing of the radioactivity incorporated into TCA-precipitable material. 
Table 3. Inhibition of incorporation of radioactivity from $\left[{ }^{14} \mathrm{C}\right]$ glucose into amino acids of hydrolysed protein of $P$. putida $\mathrm{A} 9 \mathrm{O}$ by aspartic and glutamic acids

The basal medium, containing $100 \mu \mathrm{g}$ of aspartate and $100 \mu \mathrm{g}$ of glutamate $/ \mathrm{ml}$, was incubated at $30{ }^{\circ} \mathrm{C}$. After $5 \mathrm{~min},\left[{ }^{14} \mathrm{C}\right] \mathrm{glucose}(0.2 \mu \mathrm{Ci} / \mathrm{ml})$ was added, and uptake of radioactivity measured as described in Methods.

Endogenous biosynthesis* (c.p.m./100 $\mu$ g protein hydrolysate)

\begin{tabular}{|c|c|c|c|}
\hline Amino acid & Unsupplemented & Supplemented & $\begin{array}{l}\text { Percentage } \\
\text { inhibition } \dagger\end{array}$ \\
\hline Alanine & 2175 & 1057 & $5 I$ \\
\hline Arginine & 3634 & 2259 & 38 \\
\hline Aspartate & 3981 & 1130 & 72 \\
\hline Glutamate & 4000 & 1706 & 57 \\
\hline Serine & 972 & 769 & 21 \\
\hline Glycine & I 550 & 1129 & 27 \\
\hline Threonine & 833 & $<300$ & $>64$ \\
\hline Valine & I 347 & 1322 & 2 \\
\hline Isoleucine & 1087 & $84 \mathrm{I}$ & 23 \\
\hline Leucine & 1087 & 1005 & 8 \\
\hline Histidine & 2175 & 1153 & 47 \\
\hline Lysine & 4745 & 2355 & 50 \\
\hline Phenylalanine & 972 & 875 & 10 \\
\hline Tyrosine & I I I I & $96 I$ & 14 \\
\hline Proline & 2222 & - & - \\
\hline $\begin{array}{l}\text { Cysteine and } \\
\text { cystine }\end{array}$ & $\mathrm{I} 660$ & 769 & 54 \\
\hline Methionine & I 574 & 317 & 80 \\
\hline
\end{tabular}

This could be attributed, at least in part, to the fact that a full complement of amino acids was used in the Salmonella experiment whereas aspartic and glutamic acids were omitted from the amino acid mixture used in the Pseudomonas experiment.

To determine the extent of sparing of respiration of the carbon and energy source, the rate of ${ }^{14} \mathrm{CO}_{2}$ production from radioactive asparagine in an exponentially-growing culture of $P$. putida A90 was measured before and after the addition of an amino acid supplement (Fig. 5). This rate remained essentially unchanged for about $30 \mathrm{~min}$ after the addition, and then gradually decreased to the rate characteristic of $P$. putida A90 growing exponentially on $\left[{ }^{14} \mathrm{C}\right]$ asparagine plus the same complement of amino acids.

\section{Respiration of amino acid supplement}

Since $P$. putida A90 utilizes all but two of the naturally occurring amino acids as carbon and energy sources, experiments were designed to determine if the added amino acid was catabolized. A radioactive amino acid supplement was added to $P$. putida A9o cultures growing exponentially in minimal medium at the expense of asparagine, succinate or pyruvate as sole carbon and energy sources. The evolution of significant quantities of radioactive $\mathrm{CO}_{2}$ could be detected in each case after $\mathrm{I} 5$ to $20 \mathrm{~min}$. The rate of ${ }^{14} \mathrm{CO}_{2}$ production from a $P$. putida A90 culture containing $\left[{ }^{14} \mathrm{C}\right]$ asparagine $(0.02 \mu \mathrm{Ci} / \mathrm{ml})$ plus $\left[{ }^{14} \mathrm{C}\right]$ amino acids $(0.02 \mu \mathrm{Ci} / \mathrm{ml})$ and that from a culture containing $\left[{ }^{14} \mathrm{C}\right]$ asparagine $(0.02 \mu \mathrm{Ci} / \mathrm{ml})$ plus an equivalent concentration of unlabelled amino acids remained equal 


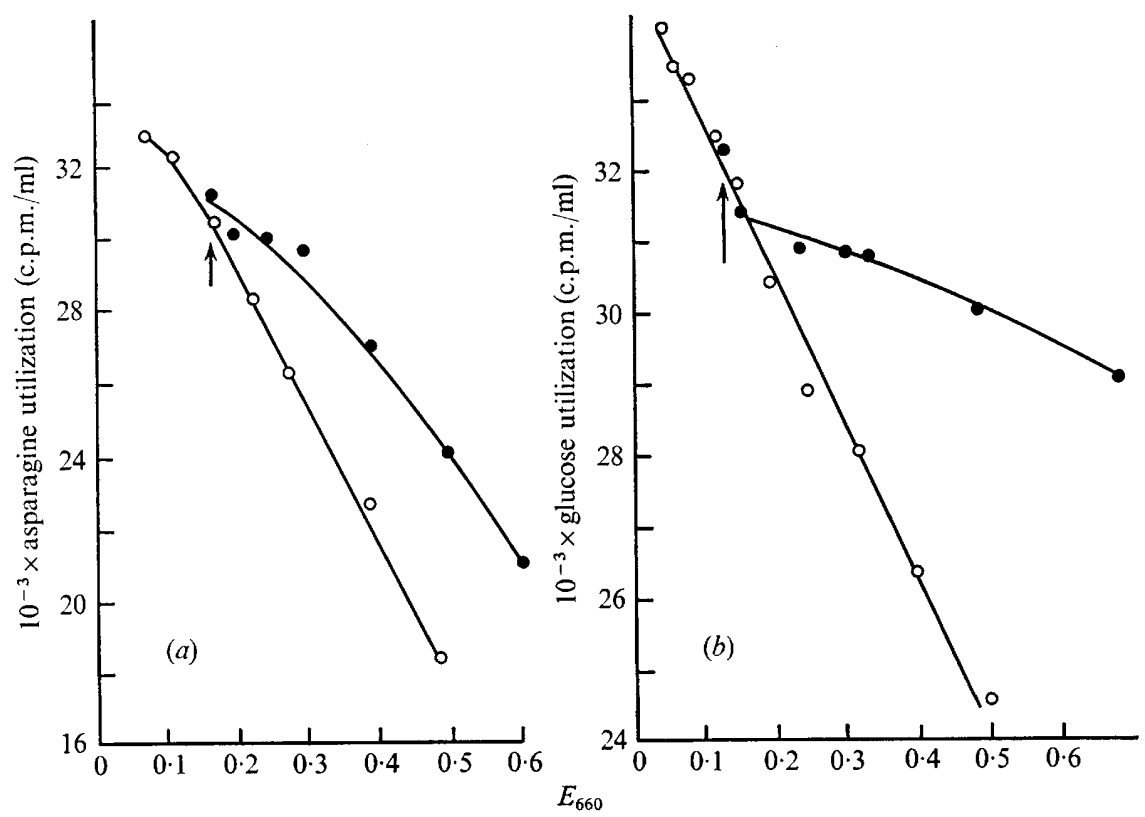

Fig. 3. (a) Effect of an amino acid supplement on asparagine utilization from the culture medium of $P$. putida A9o. The arrow indicates the time that amino acids $(20 \mu \mathrm{g}$ of each $/ \mathrm{ml}$, aspartate and glutamate omitted) were added to bacteria growing exponentially in minimal $\left[{ }^{14} \mathrm{C}\right]$ asparagine $(0.2 \%, \mathrm{w} / \mathrm{v} ; 0.02 \mu \mathrm{Ci} / \mathrm{ml})$ medium. Radioactivity (c.p.m. $/ \mathrm{ml})$ was determined in samples after removal of the bacteria by TCA precipitation and plotted as a function of cell density (extinction at $660 \mathrm{~nm}) . O,\left[{ }^{14} \mathrm{C}\right]$ asparagine utilization in minimal asparagine medium; $O$, [ $\left.{ }^{14} \mathrm{C}\right]$ asparagine utilization after addition of amino acid supplement. $(b)$ Effect of an amino acid supplement on glucose utilization from the culture medium of $S$. typhimurium LT2. The arrow indicates the time of addition of Casamino acids $(2 \mathrm{mg} / \mathrm{ml})$ to bacteria growing exponentially in minimal $\left[{ }^{14} \mathrm{C}\right] g l u c o s e$ $(0.2 \%, w / v ; 0.02 \mu \mathrm{Ci} / \mathrm{ml})$ medium. Radioactivity (c.p.m. $/ \mathrm{ml})$ of the medium was determined as in $(a) . O,\left[{ }^{14} \mathrm{C}\right]$ glucose utilization from glucose minimal medium; $O,\left[{ }^{14} \mathrm{C}\right]$ glucose utilization after addition of the amino acid supplement.

for 25 to $30 \mathrm{~min}$ after the addition of the amino acids, but subsequently the ${ }^{14} \mathrm{CO}_{2}$ evolution from the former culture increased at a substantially faster rate.

\section{ATP pool size}

It might be expected that the increased rate of ${ }^{14} \mathrm{CO}_{2}$ evolution without a significant increase in growth rate would be accompanied by an increase in the intracellular concentration of ATP in P. putida. Following supplementation of a minimal asparagine culture with a full complement of amino acids, the ATP pool remained essentially equal to that of an unsupplemented control (Fig. 6a), both decreasing slightly during the experiment. When a minimal pyruvate (slow growing) culture was supplemented with a full complement of amino acids or with asparagine alone, the ATP pool increased significantly within $30 \mathrm{~min}$ of supplementation and before the faster growth rate was observed (Fig. 6b), and then dropped gradually to its original level after the growth rate characteristic of the supplemented medium was achieved.

\section{RNA contents}

The RNA:protein ratio of $P$. putida and $S$. typhimurium cultures growing in several media were measured and compared. The RNA contents of Casamino acid-supplemented 


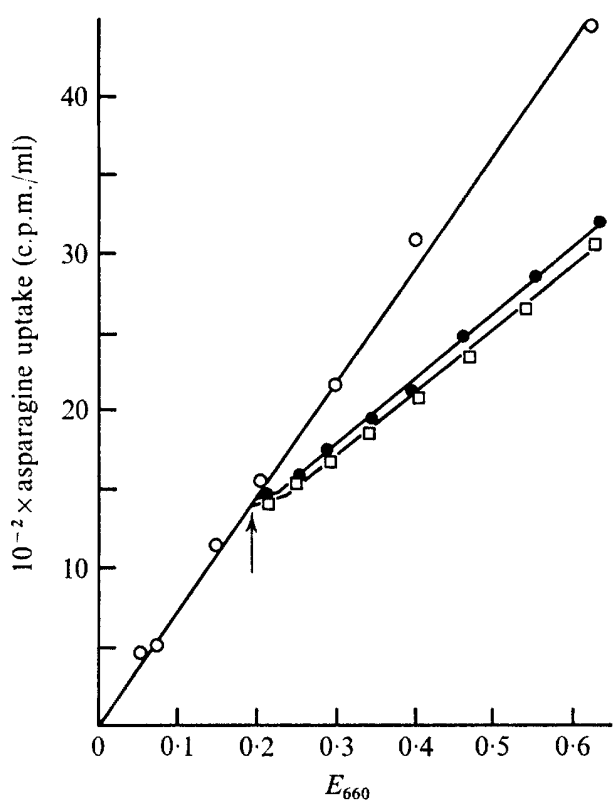

Fig. 4

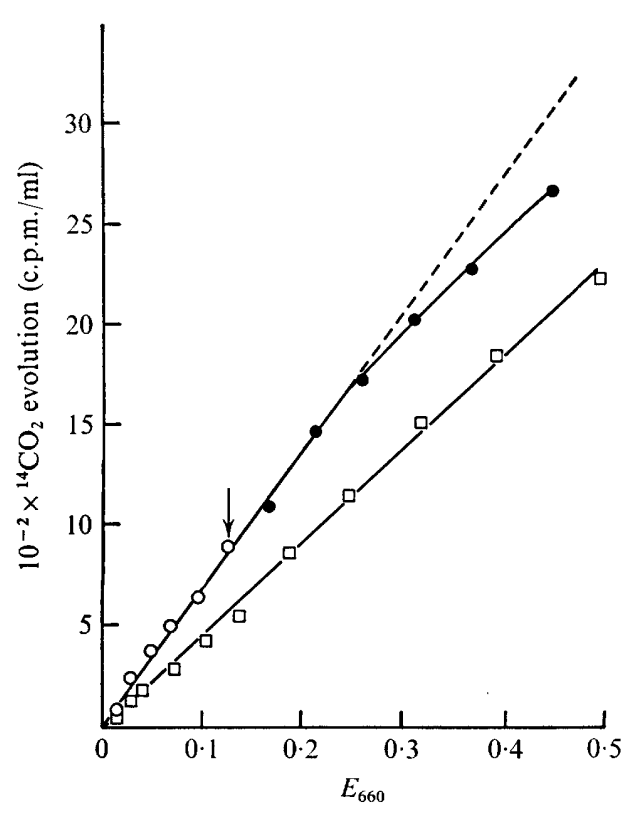

Fig. 5

Fig. 4. Effect of an amino acid supplement on the uptake of $\left[{ }^{14} \mathrm{C}\right]$ asparagine into TCA-precipitable material in a culture of $P$. putida A90. The arrow indicates the time that amino acids (aspartate and glutamate omitted) were added to bacteria growing exponentially in minimal $\left[{ }^{14} \mathrm{C}\right]$ asparagine $(0.2 \%, \mathrm{w} / \mathrm{v} ; 0.02 \mu \mathrm{Ci} / \mathrm{ml})$ medium. The radioactivity (c.p.m. $/ \mathrm{ml}$ ) of TCA-precipitable material was determined in samples of the culture and plotted as a function of growth (extinction at $660 \mathrm{~nm}$ ). $\mathrm{O},\left[{ }^{14} \mathrm{C}\right]$ asparagine uptake in minimal asparagine medium;,$\left[{ }^{14} \mathrm{C}\right]$ asparagine uptake on addition of $20 \mu \mathrm{g}$ of each amino acid $/ \mathrm{ml} ; \square,\left[{ }^{14} \mathrm{C}\right]$ asparagine uptake on addition of $100 \mu \mathrm{g}$ of each amino acid $/ \mathrm{ml}$.

Fig. 5. Effect of amino acids on the respiration of the original carbon source by $P$. putida A90. The arrow indicates the time that amino acids were added to bacteria growing exponentially in minimal $\left[{ }^{14} \mathrm{C}\right]$ asparagine $(0.2 \%, \mathrm{w} / \mathrm{v} ; 0.02 \mu \mathrm{Ci} / \mathrm{ml})$ medium. The total ${ }^{14} \mathrm{CO}_{2}$ evolved is plotted as a function of growth $\left(E_{660}\right)$. The resultant rates are compared with ${ }^{14} \mathrm{CO}_{2}$ evolution measured when the amino acid supplement was present overnight. $O,{ }^{14} \mathrm{CO}_{2}$ evolution in minimal asparagine medium;,${ }^{14} \mathrm{CO}_{2}$ evolution on addition of amino acids; $\square,{ }^{14} \mathrm{CO}_{2}$ evolution in a culture grown overnight in asparagine + amino acids. The $E_{660}$ value at zero time was subtracted from each $E_{660}$ value.

minimal asparagine- and nutrient broth-grown $P$. putida were only 6 and I $2 \%$ higher respectively than minimal asparagine-grown bacteria. In contrast, the RNA concentrations of $S$. typhimurium grown in Casamino acid-supplemented glucose minimal medium and in nutrient broth were 38 and $49 \%$ higher respectively than that of minimal glucose-grown organisms. Consistent with this observation was the finding that when the rate of RNA synthesis was measured on shift-up from minimal asparagine to an amino acid-supplemented medium, little increase in rate occurred with either $P$. putida A90 or strain A775 (Fig. I). Furthermore, no immediate increase in the rate of RNA accumulation was observed on transition from a medium which supports growth at a low rate (minimal pyruvate) to one which supports growth at a high rate (minimal pyruvate plus amino acids); the growth rate and the rate of RNA synthesis remained essentially unchanged for $30 \mathrm{~min}$ after shift, after which they increased gradually to the rate characteristic of the complex medium (Fig. 2). A similar result was obtained when asparagine was the supplement rather than a full complement of amino acids. 

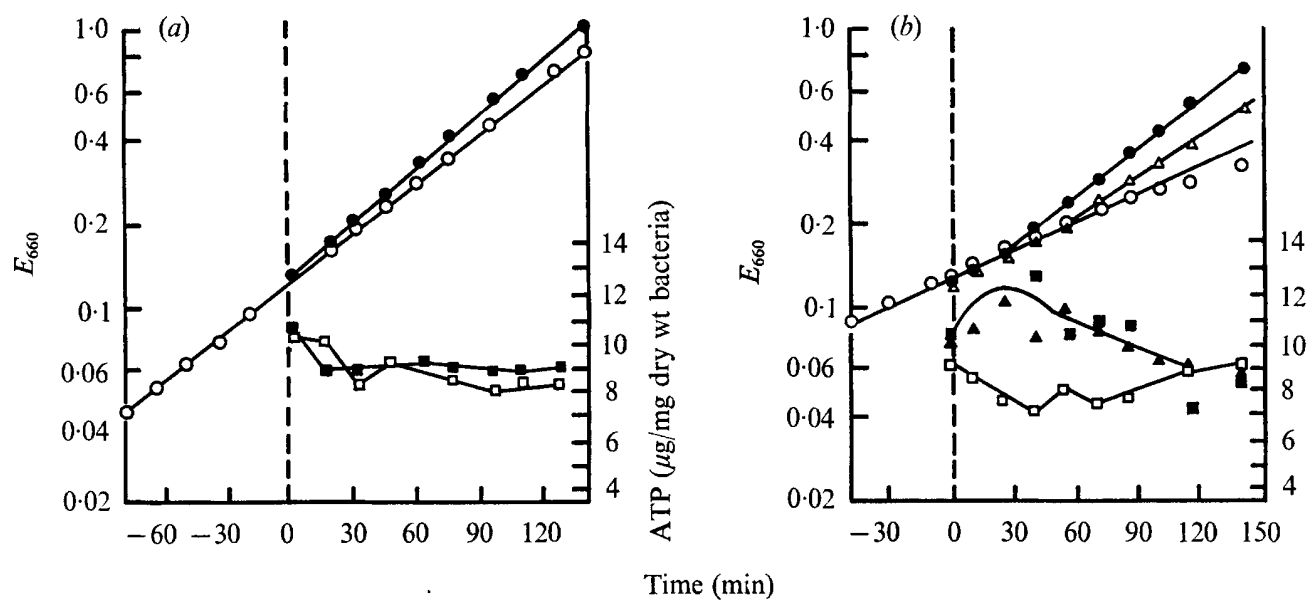

Fig. 6. ATP pool concentration during shift-up experiments with $P$. putida A9o. (a) Twenty amino acids $(20 \mu \mathrm{g}$ of each $/ \mathrm{ml})$ were added at zero time to an exponentially-growing $0.2 \%(\mathrm{w} / \mathrm{v})$ asparagine culture. $O$, Growth $\left(E_{660}\right)$ in minimal asparagine; $O$, growth in asparagine+amino acids; $\square$, ATP concentration in bacteria from minimal asparagine culture; $\boldsymbol{\square}$, ATP concentration in bacteria from asparagine + amino acids culture. (b) Casamino acids or asparagine were added at zero time to exponentially-growing minimal pyruvate cultures. For concentrations, see Table I. $O$, Growth $\left(E_{680}\right)$ in minimal pyruvate; $\boldsymbol{O}$, growth in pyruvate + Casamino acids; $\triangle$, growth in pyruvate + asparagine; $\square$, ATP concentration in bacteria from minimal pyruvate culture; w, ATP concentration in bacteria from pyruvate + Casamino acids culture; $\boldsymbol{\Delta}$, ATP concentration in bacteria from pyruvate + asparagine culture.

Table 4. RNA content expressed as the RNA:protein ratio of $P$. putida A9O growing at various growth rates in different media

$\begin{array}{ccc}\text { Carbon and energy source* } & \begin{array}{c}\text { Specific growth rate } \\ \left(\mathrm{h}^{-1}\right)\end{array} & \begin{array}{c}\text { RNA: protein ratio } \\ (\mathrm{mg} R N A / m g \text { protein) }\end{array} \\ \text { alonate }(0.4) & 0.4 \mathrm{I} & 0.30 \\ \text { ruvate }(0.4) & 0.475 & 0.348 \\ \text { ucose }(0.2) & 0.693 & 0.475 \\ \text { nzoate }(0.2) & 0.83 \mathrm{I} & 0.53 \\ \text { paragine }(0.2) & 0.925 & 0.6 \\ \text { sparagine }(0 \cdot 2) \text { + Casamino acids }(0.2) & \mathbf{I} \cdot 0 & 0.64 \\ \text { utrient broth (Oxoid) } & \mathbf{I} \cdot 04 & 0.675\end{array}$

* Concentrations $(\%, w / v)$ are given in parentheses.

Apart from the lack of immediate response on addition of amino acids, RNA synthesis in $P$. putida A90 appears to be regulated in a manner similar to the enteric bacteria. Pseudomonas putida A90 varied its RNA content directly as a function of specific growth rate (Table 4). These bacteria achieved a near maximal RNA content in minimal media with a good carbon and energy source.

Pseudomonas putida A90 exerts a stringent control on RNA synthesis. When bacteria were shifted from an amino acid-supplemented medium to minimal asparagine medium, neither growth nor RNA accumulation ceased completely (Fig. 7) but continued at approximately equivalent slow rates before gradually adopting the rates characteristic of unsupplemented asparagine medium. On withdrawal of its essential amino acids from an isoleucine-valine auxotroph of $P$. putida, stable RNA synthesis ceased (Fig. 8). When trimethoprim, which 


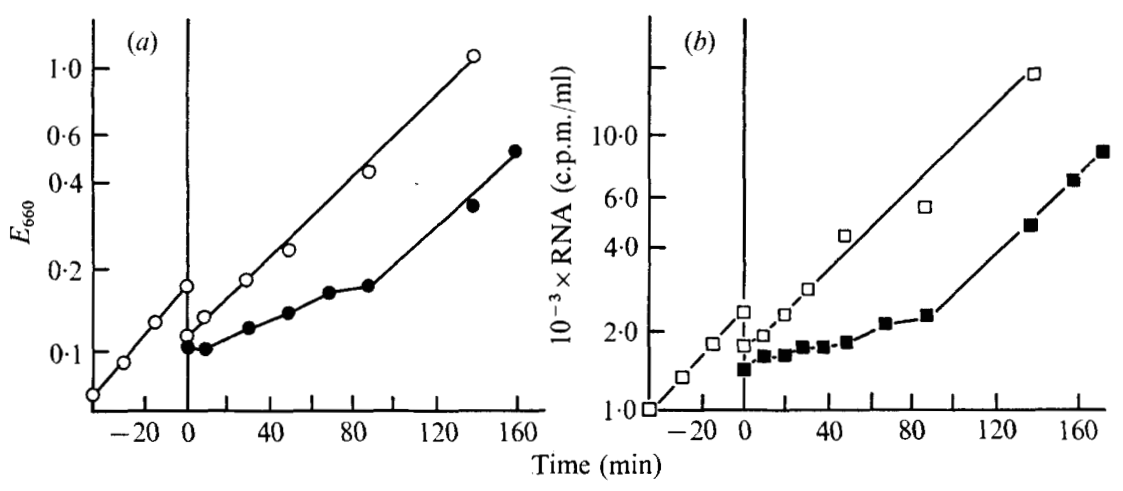

Fig. 7. (a) Growth $E_{660}$ and (b) RNA synthesis (c.p.m./ml of $\left[{ }^{14} \mathrm{C}\right]$ uracil uptake into TCA precipitate) during a shift-down experiment with $P$. putida A90. Bacteria grown in minimal asparagine + Casamino acids medium (see Table I) were harvested by centrifugation, washed and transferred at zero time to minimal asparagine medium. $O$, Growth in asparagine + Casamino acids;, Growth in minimal asparagine; $\square$, RNA in asparagine + Casamino acids; $\mathbf{\square}$, RNA in minimal asparagine.

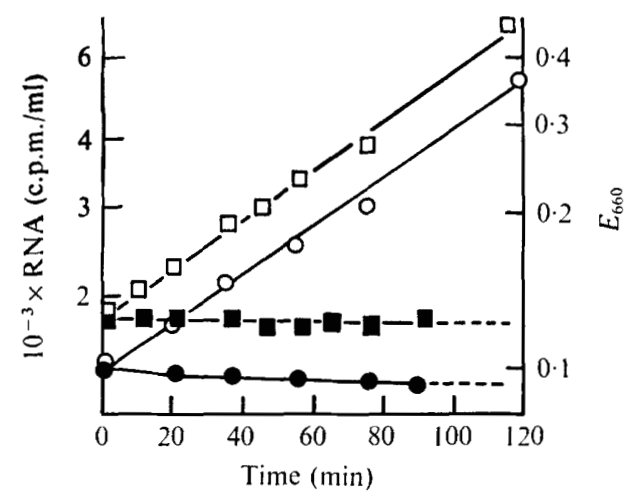

Fig. 8. Growth $E_{660}$ and RNA synthesis (c.p.m./ml of $\left[{ }^{14} \mathrm{C}\right]$ uracil uptake into TCA precipitate) on withdrawal of its essential amino acids from $P$. putida A90 $i l v^{-}$. Exponentially-growing bacteria in $0.2 \%(\mathrm{w} / \mathrm{v})$ asparagine medium, supplemented with $50 \mu \mathrm{g}$ each of isoleucine and valine $/ \mathrm{ml}$, were harvested, washed and divided into two portions. One portion was added to minimal asparagine medium and the remainder to minimal asparagine + valine +isoleucine medium. $O$, Growth in asparagine + isoleucine + valine; 0 , growth in minimal asparagine; $\square$, RNA in asparagine + isoleucine + valine; $\mathbf{\square}$, RNA in minimal asparagine.

immediately inhibits RNA synthesis in enteric bacteria, was added to $P$. putida A9o cultures, no abrupt cessation of RNA synthesis was observed, the rates of RNA synthesis and growth decreasing gradually after $20 \mathrm{~min}$. The effect of chloramphenicol on RNA synthesis in $P$. putida A90 cultures growing in either minimal or amino acid-supplemented asparagine medium, was similar to its effect on the enteric bacteria, i.e. it allowed RNA synthesis to continue at reduced levels of protein synthesis. This was the only experiment in which RNA accumulation was significantly dissociated from active growth with $P$. putida A90. 


\section{DISCUSSION}

The isotopic competition experiments show that a $70 \%$ decrease in the carbon source being channelled to protein synthesis was achieved within 5 min of amino acid supplementation, and that most, if not all, the amino acid biosynthetic pathways were regulated by feedback inhibition in P. putida A90. As Abelson (1954) found in Escherichia coli, amino acid pathways which were several steps removed from the Krebs cycle and which had no other role in biosynthesis were more tightly regulated than the pathways close to the cycle.

Pseudomonads degrade many compounds, including amino acids, by inducible catabolic pathways (Jacoby, I964; Palleroni \& Stanier, I964; Stanier et al., I966; Gryder \& Adams, 1969; Marshall \& Sokatch, 1972). We found that $P$. putida A90 respired a significant fraction of a full complement of exogenously supplied amino acids even in the presence of a good carbon source like asparagine, confirming the observation (Hegeman, 1966; Palleroni \& Stanier, 1964; Condon, 1967) that asparagine does not elicit a significant catabolite repression response in $P$. putida A90, which differs in this respect from glucose-grown enteric bacteria. Pseudomonas putida probably prevents the catabolism of endogenously synthesized amino acids by maintaining relatively low amino acid pools through tight feedback inhibition as Kay \& Gronlund (1969) demonstrated with $P$. aeruginosa, and these pools probably never rise to the level required for induction of catabolic enzymes. Exogenous amino acids could swell these pools to a concentration which would cause enzyme induction.

Amino acid supplementation of a $P$. putida A90 minimal culture should spare the carbon and energy source, as a consequence of extensive feedback inhibition of anabolic pathways, coupled with respiration of the amino acid supplement. This was indeed observed, but the effect was not so great as that of a $S$. typhimurium culture in a similar experiment. The sparing effect could be accounted for in both cases by a decrease in the amount of growth substrate being channelled into macromolecules and a decrease in the amount being respired to provide energy. The reduction in respiration rate of the initial carbon source on supplementation with amino acids was not observed until after a doubling of cell mass had taken place, and gradually developed at approximately the time that respiration of the amino acid supplement becomes significant. No increase in the ATP pool was observed under these conditions.

An increase in ribosome concentration is also a critical factor for bacteria to increase their growth rate when nutritional supplements are added. The RNA content of $P$. putida A90 varied directly as a function of specific growth rate up to a maximal value which was achieved in a minimal medium with a single good carbon and energy source. Exogenous amino acids barely stimulated the rate of RNA accumulation, and it is probable that this is the growth rate-limiting factor in $P$. putida.

The control of stable RNA synthesis in P. putida, like that in the enteric bacteria, is closely associated with protein synthesis. Pseudomonas putida auxotrophs exhibited a typical stringent RNA synthesis response on amino acid starvation. The inhibition by trimethoprim of stable RNA synthesis and growth of $P$. putida A90 was not immediate and thus differed from that in E. coli (Miovic \& Pizer, 197I). The response to chloramphenicol in P. putida cultures, however, was similar to that observed with the enteric bacteria (Fraenkel \& Neidhardt, I96I; Kurland \& Maaløe, I962).

Amino acid supplementation of enteric bacteria growing in glucose minimal media represses amino acid biosynthetic pathways and, because of catabolite repression, does not impose any new synthetic activities on these cells. As a consequence, RNA polymerase molecules involved in synthesis of mRNA in minimal medium are available to synthesize 
ribosomal RNA on shift-up (Nierlich, I972 $a, b$; Bremer, Berry \& Dennis, 1973). However, in $P$. putida little repression of biosynthetic enzyme synthesis follows amino acid supplementation of minimal cultures (Udaka, 1966; Stalon et al., 1967; Robert-Gero, Poiret \& Cohen, I970; Maurer \& Crawford, I97I; Condon, Collins \& O’Donovan, I976) and the lack of catabolite repression allows induction of enzymes which catabolize the amino acid supplement. RNA polymerase molecules engaged in mRNA synthesis in minimal medium therefore may not be free to switch to the synthesis of rRNA on shift-up of $P$. putida. We suggest that, in $P$. putida, the lack of such a shift-up response is due to inability to synthesize additional ribosomal RNA, which in turn may be due to RNA polymerase molecules being unavailable on shift-up. We are at present seeking evidence for this hypothesis.

We thank Liam Burgess and Pat Higgins for technical assistance.

\section{REFERENCES}

Abelson, P. H. (1954). Amino acid biosynthesis in Escherichia coli: isotopic competition with ${ }^{14} \mathrm{C}$ glucose. Journal of Biological Chemistry 206, 335-343.

Abelson, P. H., Bolton, E. T. \& Aldous, E. (I952). Utilization of carbon dioxide in the synthesis of proteins by Escherichia coli. I. Journal of Biological Chemistry I98, I65-185.

BREMER, H., BERRY, L. \& DeNNIS, P. P. (I973). Regulation of ribonucleic acid synthesis in Escherichia coli $\mathrm{B} / \mathrm{r}$ : an analysis of a shift up. II. Fraction of RNA polymerase engaged in the synthesis of stable RNA at different steady-state growth rates. Journal of Molecular Biology 75, 16i-I 79 .

Cohen-Bazire, G., Sistrom, Q. R. \& Stanier, R. Y. (1957). Kinetic studies of pigment synthesis by nonsulphur purple bacteria. Journal of Cellular and Comparative Physiology 49, 25-68.

Cole, H. A., WiMPENNy, J. W. T. \& Hughes, D. E. (1967). The ATP pool in Escherichia coli. I. Measurement of the pool using a modified luciferase assay. Biochimica et biophysica acta 143, 445-453.

Condon, S. (1967). Cold-sensitive mutants of Pseudomonas putida. Ph.D. thesis, University of California, Davis, U.S.A.

Condon, S., Collins, J. K. \& O'Donovan, G. A. (1976). Regulation of arginine and pyrimidine biosynthesis in Pseudomonas putida. Journal of General Microbiology 92, 375-383.

FORREST, W. W. \& WALKER, D. J. (1965). Synthesis of reserve materials for endogenous metabolism in Streptococcus faecalis. Journal of Bacteriology 89, I448-I452.

FraenKel, D. G. \& NeIdHARDT, F. C. (1961). Use of chloramphenicol to study control of RNA synthesis in bacteria. Biochimica et biophysica acta 53, 96-110.

GrYDER, R. M. \& ADAMS, E. (I969). Inducible degradation of hydroxyproline in Pseudomonas putida: pathway regulation and hydroxyproline uptake. Journal of Bacteriology 97, 292-306.

HeathCote, J. G. \& Haworth, C. (1969). An improved technique for the analysis of amino acids and related compounds on thin layers of cellulose. II. The quantitative determination of amino acids in protein hydrolysates. Journal of Chromatography 43, 84-92.

Hegeman, G. D. (1966). Synthesis of the enzymes of the mandelate pathway by Pseudomonas putida. I. Synthesis of enzymes by the wild type. Journal of Bacteriology 9I, I I40-I I 54.

JACOBY, G. A. (1964). The induction and repression of amino acid oxidation in Pseudomonas fluorescens. Biochemical Journal 92, I-8.

KAY, W. W. \& Gronlund, A. F. (1969). Amino acid pool formation in Pseudomonas aeruginosa. Journal of Bacteriology 97, 282-291.

KuRLAND, C. G. \& MAALøE, O. (1962). Regulation of ribosomal and transfer RNA synthesis. Journal of Molecular Biology 4, 193-210.

Lowry, O. H., Rosebrough, N. J., Farr, A. L. \& Randall, R. J. (I95I). Protein measurement with the Folin phenol reagent. Journal of Biological Chemistry I93, 265-275.

McGinnis, J. F. \& PAIGEN, K. (I969). Catabolite inhibition: a general phenomenon in the control of carbohydrate utilisation. Journal of Bacteriology 100, 902-913.

MaAløe, O. \& KJeldgaARd, N. O. (1966). Control of Macromolecular Synthesis. New York and Amsterdam: W. A. Benjamin.

Marshall, V. P. \& Sokatch, J. R. (1972). Regulation of valine catabolism in Pseudomonas putida. Journal of Bacteriology I10, 1073-1081.

MAURER, R. \& CRAWFORD, I. P. (I97I). New regulatory mutation affecting some of the tryptophan genes in Pseudomonas putida. Journal of Bacteriology 106, 331-338.

Miovic, M. \& PIZER, L. (197I). Effect of trimethoprim on macromolecular synthesis in Escherichia coli. Journal of Bacteriology 106, 856-862. 
Munro, H. N. \& FleCK, A. (1966). The determination of nucleic acids. Methods of Biochemical Analysis I4, $113-176$.

NeIDHARDT, F. C. \& MAGASANIK, B. (1960). Studies on the role of ribonucleic acid in the growth of bacteria. Biochimica et biophysica acta 42, 99-1 16.

NiERLICH, D. P. (1972a). Regulation of ribonucleic acid in growing bacterial cells. I. Control over the total rate of RNA synthesis. Journal of Molecular Biology 72, 75I-764.

NIERLICH, D. P. (1972b). Regulation of ribonucleic acid synthesis in growing bacterial cells. II. Control over the composition of the newly made RNA. Journal of Molecular Biology 72, 765-777.

Palleroni, N. J. \& Stanier, R. Y. (I964). Regulatory mechanisms governing synthesis of the enzymes for tryptophan oxidation by Pseudomonas fluorescens. Journal of General Microbiology 35, 319-334.

Robert-Gero, M., Poiret, M. \& Cohen, G. N. (I970). The aspartate kinase of Pseudomonas putida. Regulation of synthesis and activity. Biochimica et biophysica acta 206, 17-30.

Schaechter, M., Maaløe, O. \& KJeldgaARD, N. O. (1958). Dependency on medium and temperature of cell size and chemical composition during balanced growth of Salmonella typhimurium. Journal of General Microbiology 19, 592-606.

Stalon, V., Ramos, F., Pierard, A. \& Wiame, J. M. (1967). The occurrence of a catabolic and an anabolic ornithine carbamoyltransferase in Pseudomonas. Biochimica et biophysica acta 139, $9 \mathrm{I}-97$.

Stanier, R. Y., Palleroni, N. J. \& Doudoroff, M. (1966). The aerobic pseudomonads: a taxonomic study. Journal of General Microbiology 43, I 59-27I.

UdAKA, S. (1966). Pathway-specific pattern of control of arginine biosynthesis in bacteria. Journal of Bacteriology 91, 617-627. 